\title{
Spring oceanographic conditions and northern shrimp Pandalus borealis recruitment success in the north-western Gulf of St. Lawrence
}

\author{
Patrick Ouellet* ${ }^{*}$ Louise Savard, Pierre Larouche \\ Maurice Lamontagne Institute, Fisheries and Oceans Canada, 850 route de la mer, Mont-Joli, Quebec G5H 3Z4, Canada
}

\begin{abstract}
Time series of sea-surface temperature (SST), thermally mixed layer depth, and the SST warming rate in spring at the time of larval emergence were correlated with indices of northern shrimp Pandalus borealis recruitment (cohort abundance and larval survival index) between 1994 and 2003 in the northwest Gulf of St. Lawrence, Canada. The recruitment index and larval survival index were negatively correlated to daily mean SST at the time of larval emergence. The recruitment index and larval survival index were positively correlated with the SST warming rate and with the mixed layer depth at the time of larval emergence. Overall, the analysis reveals that larval emergence during a period of weak density stratification and low SST in the spring, but followed by relatively high warming rates of the upper layer of the water column, is favourable for larval survival. We suggest that the observed relationships support the hypothesis that oceanographic conditions in the upper layer of the water column, which initiate and sustain high levels of biological production at the time of larval emergence and early development, are favourable for northern shrimp recruitment success. Thus, interannual variability in northern shrimp recruitment in the northwest Gulf of St. Lawrence may be explained by Cushing's match/mismatch hypothesis.
\end{abstract}

KEY WORDS: Northern shrimp · Sea-surface temperature $\cdot$ Recruitment $\cdot$ Match/mismatch $\cdot$ Gulf of St. Lawrence $\cdot$ Pandalus borealis

\section{INTRODUCTION}

The northern shrimp Pandalus borealis (Krøyer) is a dominant crustacean decapod species in the St. Lawrence Estuary and the Gulf of St. Lawrence (GSL) ecosystem that has supported an important commercial fishery since the mid-1960s (Savard et al. 2003). Northern shrimp is particularly abundant in the northern GSL, where depths and bottom temperatures are suitable for its establishment. Juveniles are found at the head of the deep channels. They carry out ontogenetic migrations, and the adults are found in deeper waters where they are abundant enough to be exploited. The north-western sector of the Gulf of St. Lawrence (NW GSL) sustains the most abundant concentration and the most important fishery. This shrimp population is assumed to be self-sustained and is managed as a single stock. Long-term monitoring showed that the stock biomass has fluctuated through time, possibly as a function of recruitment fluctuations (Savard \& Bouchard 2004). Small-mesh bottom trawl surveys conducted in October from 1998 to 2004 in the St. Lawrence Estuary (in a zone adjacent to the NW GSL) revealed that post-larval abundance varies greatly between years, indicating that the strength of a year-class could be determined during the larval pelagic phase (L. Savard unpubl. data).

Mature females spawn in late summer or early fall in the northern Gulf of St. Lawrence and carry their fertilised eggs on their pleopods until the larvae hatch 8 to 9 mo later, in late April. The larvae are planktonic, and the complete sequence of larval development at sea the pelagic phase of the life cycle - passes through 5 instars (4 moults) and is estimated to last up to 3 mo 
before the first juveniles descend to the bottom (Ouellet \& Allard 2006).

In the NW GSL, the first 3 larval stages are present in the water column until early June and are concentrated in the upper layer of the stratified water column, where favourable feeding conditions are expected (Ouellet \& Lefaivre 1994, Ouellet \& Allard 2006). Gut content and biochemical analyses of field-caught larvae suggest that phytoplankton may constitute a significant proportion of the diet of the first larval stages at sea (Stickney \& Perkins 1981, Pedersen \& Storm 2002). However, in the laboratory, phytoplankton cells alone cannot support Pandalus borealis larval development and growth (Ouellet et al. 1992). Stage I and II larvae have a higher clearance rate for algal food than for other (animal) food items, but Stage III and older larvae seem to ignore phytoplankton cells (Rasmussen et al. 2000).

Investigations carried out in different oceanic regions have suggested that variability in the physical conditions and the spring biological production cycles influences Pandalus borealis abundance and growth (Anderson 2000, Parsons \& Colbourne 2000, FuentesYaco et al. 2007). More generally, the notion that variability in larval survival arises from annual variations in the temporal and/or spatial overlap between larvae and prey is still a popular explanation for recruitment success in aquatic animal populations (Cushing 1990, Platt et al. 2003, Edwards \& Richardson 2004, Head et al. 2005). In most scenarios, it is the timing of prey production that varies most relative to the spawning and/or hatching time. However, a recent study in the North Sea suggests that the timing of spring diatom blooms may be relatively stable, possibly because factors such as day length and light intensity are more important than water temperature to determine their initiation (Edwards \& Richardson 2004). On the other hand, monitoring of the fisheries in the Gulf of St. Lawrence showed that shrimp spawning and hatching dates could vary from one year to the next.

In this study, our objective was to investigate fluctuations of northern shrimp recruitment in the Gulf of St. Lawrence (Canada). An examination of the spring oceanographic conditions, particularly the density and thermal structure of the upper water column, and the shrimp recruitment variations combined with our knowledge of the ecology of shrimp larvae in this system led us to propose that the timing of larval emergence relative to the initiation and development of the biological production cycle is critical for northern shrimp recruitment success. We suggest that integrating reproductive potential (egg production), bio-physical modelling of plankton production, and individual-based modelling (IBM) of larval development and growth could allow the anticipation of changes in shrimp abundance in the GSL and the northwest Atlantic.

\section{MATERIALS AND METHODS}

Overview of the surface circulation pattern in the Gulf of St. Lawrence. The annually averaged surface layer circulation pattern over the entire GSL can be qualified as cyclonic and estuarine-like (e.g. El-Sabh 1976, Koutitonsky \& Bugden 1991). The 'estuarine' character of the circulation is dominated by the outflow of the St. Lawrence River, from the lower estuary to the southern GSL, through a strong coastal jet (the Gaspé Current) moving along the Gaspé Peninsula (Fig. 1). Water entering through the Cabot Strait (east side) and moving up along the Newfoundland coast and inflow from the Strait of Belle Isle in the northeast, with contributions from river runoff on the Quebec North Shore, produce a westward current along the north shore that completes the overall cyclonic pattern (Fig. 1). At smaller timescales and over most of the GSL area, however, the surface circulation pattern is much more complex, with atmospheric, hydrologic and oceanic forcing leading to the formation of eddies, coastal upwelling and density fronts that superimpose on the mean circulation pattern (e.g. Saucier et al. 2003). In addition, seasonal variability with the lowest estimated transport (outflow at the Cabot Strait) in winter and early spring, intensification in summer and peak transport in the fall has been suggested for the GSL system (Saucier et al. 2003, Han 2004). For our study area in particular, the NW GSL is characterised by a quasi-permanent cyclonic gyre that links several dynamical processes such as the Gaspé Current, transverse currents at the mouth of the estuary and coastal upwelling along the north shore, all of which show important synoptic variability (El-Sabh 1976, Koutitonsky \& Bugden 1991, Saucier et al. 2003). However, most of our knowledge of the upper-layer dynamics comes from numerical simulations (e.g. Saucier et al. 2003), and there are still large uncertainties regarding exchanges and residence time of the plankton and water masses among regions/sectors of the GSL.

Oceanographic data. The investigation of oceanographic conditions for northern shrimp Pandalus borealis recruitment was restricted to the NW GSL and the period from 1990 to 2004 (Fig. 1, Table 1). This sector sustains the most important shrimp stock in the GSL, and the fishery sampling program allows the monitoring of the annual variations in the population biological characteristics. Although shrimp exploitation level in the NW GSL has been stable since the early 1990s, shrimp biomass has fluctuated greatly during the 1990s and the first decade of 2000. The biomass decreased between 1990 and 1992, increased up to 1997 , fluctuated without a trend between 1997 and 2002 and then increased sharply in 2003 (Savard \& Bouchard 2004). The general increase during the second half of 

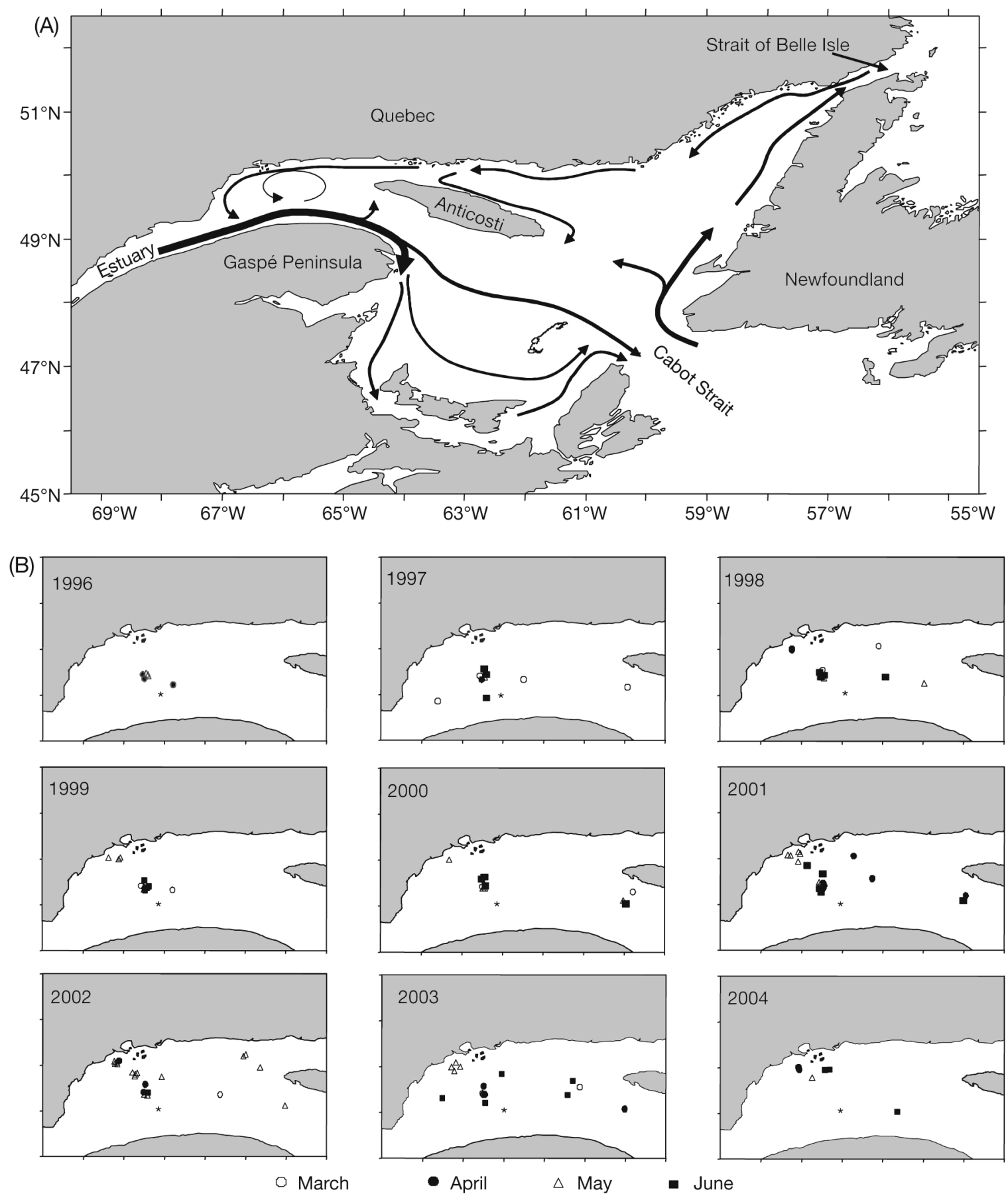

Fig. 1. (A) Simple illustration of the annually averaged large-scale surface layer circulation pattern for the Gulf of St. Lawrence (GSL, see 'Materials and methods: Overview ...' for description). (B) Position of the fixed monitoring station for the annual seasurface temperature (SST) time series (asterisk) and the position (average when $>1$ profile was available for a given day), per month for each year, of the CTD profiles retained for the analysis for 1996 to 2004

the 1990s could be attributed to a decrease in mortality due to the collapse of groundfish stocks (Savenkoff et al. 2006). However, the yearly fluctuations since 1997 have been attributed to variations in the strength of the year-classes recruiting to the fishable stock (Savard \& Bouchard 2004).
Time series of daily mean sea-surface temperature (SST) for the spring (March to end of June) were constructed from 3 independent data sources: (1) all available conductivity temperature depth (CTD) profiles between March and the end of June at stations with depths $>100 \mathrm{~m}$ and excluding the influence of the 
Table 1. Pandalus borealis. Availability (by year) of different sources of data used to investigate northern shrimp recruitment processes in the north-western Gulf of St. Lawrence. Before 1996, very few CTD profiles were available for several months between March and June

\begin{tabular}{|c|c|c|c|c|c|c|c|c|c|c|c|c|c|c|c|}
\hline Data & '90 & '91 & '92 & '93 & '94 & '95 & '96 & '97 & '98 & '99 & '00 & '01 & '02 & '03 & '04 \\
\hline \multicolumn{16}{|c|}{ Sea-surface temperature } \\
\hline Fixed station & & & & & $\mathrm{X}$ & $\mathrm{X}$ & $\mathrm{X}$ & $\mathrm{X}$ & $\mathrm{X}$ & $\mathrm{X}$ & $\mathrm{X}$ & $\mathrm{X}$ & $\mathrm{X}$ & $\mathrm{X}$ & $\mathrm{X}$ \\
\hline CTD & $\mathrm{X}$ & $\mathrm{X}$ & $\mathrm{X}$ & $\mathrm{X}$ & $\mathrm{X}$ & $\mathrm{X}$ & $\mathrm{X}$ & $\mathrm{X}$ & $\mathrm{X}$ & $\mathrm{X}$ & $\mathrm{X}$ & $\mathrm{X}$ & $\mathrm{X}$ & $\mathrm{X}$ & $\mathrm{X}$ \\
\hline Satellite & & & & & $\mathrm{X}$ & $\mathrm{X}$ & $\mathrm{X}$ & $\mathrm{X}$ & $\mathrm{X}$ & $\mathrm{X}$ & $\mathrm{X}$ & $\mathrm{X}$ & $\mathrm{X}$ & $\mathrm{X}$ & $\mathrm{X}$ \\
\hline Sea-surface chl a & & & & & & & & & $\mathrm{X}$ & $\mathrm{X}$ & $\mathrm{X}$ & $\mathrm{X}$ & $\mathrm{X}$ & $\mathrm{X}$ & $\mathrm{X}$ \\
\hline Winter ice & $\mathrm{X}$ & $\mathrm{X}$ & $\mathrm{X}$ & $\mathrm{X}$ & $\mathrm{X}$ & $\mathrm{X}$ & $\mathrm{X}$ & $\mathrm{X}$ & $\mathrm{X}$ & $\mathrm{X}$ & $\mathrm{X}$ & $\mathrm{X}$ & $\mathrm{X}$ & $\mathrm{X}$ & $\mathrm{X}$ \\
\hline Emergence date & & & $\mathrm{X}$ & $\mathrm{X}$ & $\mathrm{X}$ & $\mathrm{X}$ & $\mathrm{X}$ & $\mathrm{X}$ & $\mathrm{X}$ & $\mathrm{X}$ & $\mathrm{X}$ & $\mathrm{X}$ & $\mathrm{X}$ & $\mathrm{X}$ & $\mathrm{X}$ \\
\hline Recruitment & & $\mathrm{X}$ & $\mathrm{X}$ & $\mathrm{X}$ & $\mathrm{X}$ & $\mathrm{X}$ & $\mathrm{X}$ & $\mathrm{X}$ & $\mathrm{X}$ & $\mathrm{X}$ & $\mathrm{X}$ & $\mathrm{X}$ & $\mathrm{X}$ & $\mathrm{X}$ & \\
\hline
\end{tabular}

strong coastal current on the north shore of the Gaspé Peninsula (Fig. 1), (2) data from a surface $(0.5 \mathrm{~m})$ temperature probe on a buoy at a fixed monitoring station located in the NW GSL $\left(49.53^{\circ} \mathrm{N}, 65.75^{\circ} \mathrm{W}\right)$ and (3) SSTs extracted from NOAA-AVHRR satellite images in a $3 \times 3$ pixel box $(3 \times 3 \mathrm{~km})$ corresponding to the position of the fixed monitoring station. That station was selected because it represents well the SST variance over the entire NW GSL (Ouellet et al. 2003). The nearsurface temperature series recorded at 30 min intervals at the monitoring station served as the reference time series from which daily mean SSTs were estimated for each year. However, in some years, the buoy
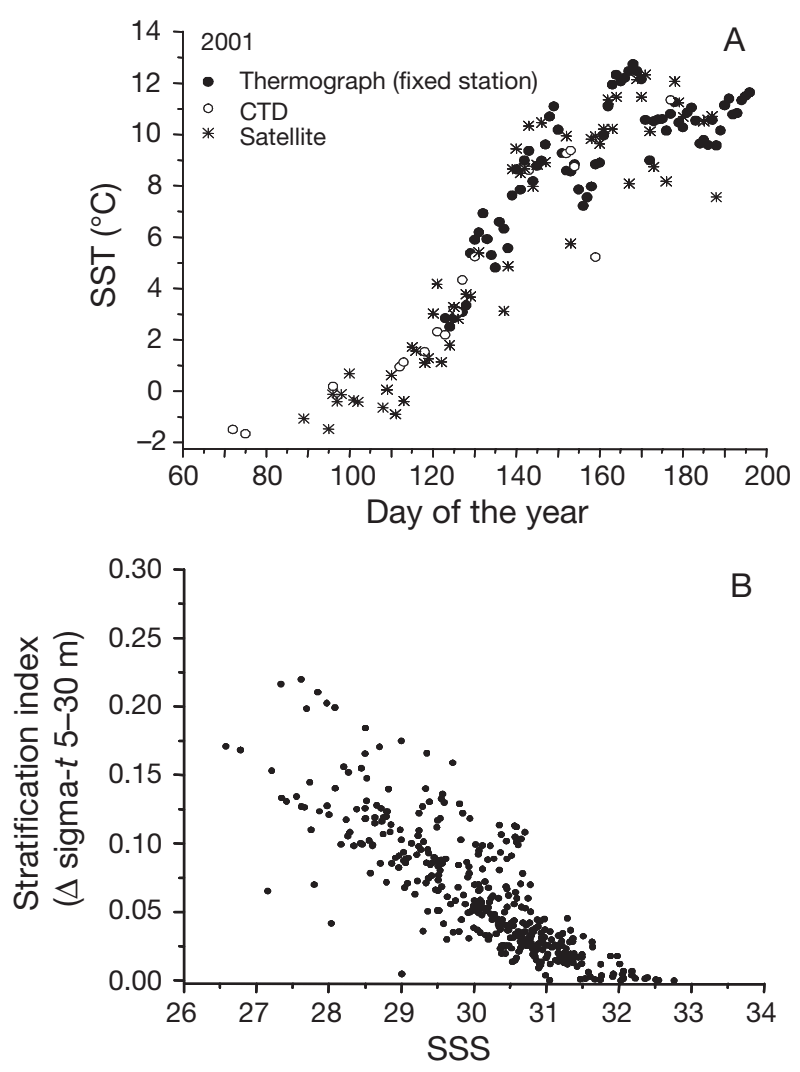

was moored late in the spring (e.g. mid-May), so the available CTD profiles and, especially, the satellite data were then used to extend the daily mean SST series backward to earlier in spring (to the beginning of March). There was always good agreement between the 3 SST data series (Fig. 2A). Therefore, all data were combined to obtain a daily mean SST time series from the end of March to the end of June for the 1994 to 2004 period. In addition, a climatological daily mean SST for the 11 yr period and standardised daily anomalies for each year were also estimated.

Using the daily mean SST data series and the CTD profile data, we derived different indices of physical

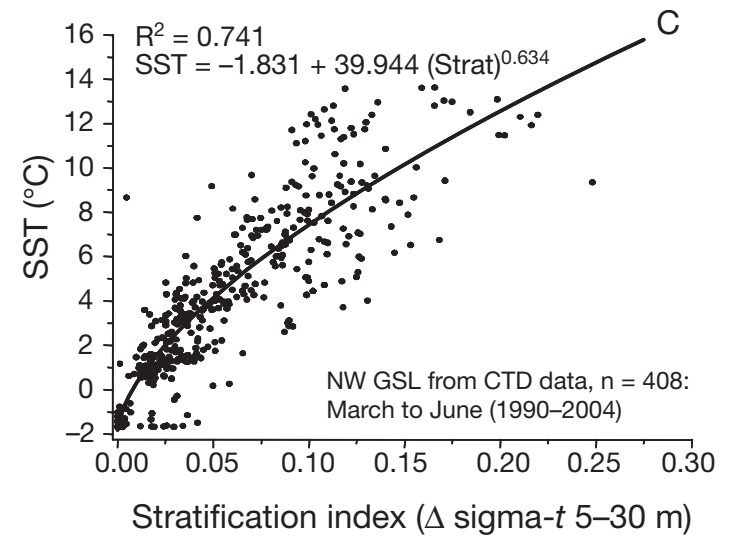

Fig. 2. North-western Gulf of St. Lawrence (NW GSL). (A) Similarity of daily mean SST estimated from 3 sources of data (thermograph at fixed station, CTD profiles, satellite); 2001 data are shown. (B) Relationship between sea-surface salinity (SSS) and the density stratification index from all CTD profiles available from 1990 to 2004. (C) Prediction of SST from the density stratification index estimated from all CTD profiles available from 1990 to 2004 
oceanographic conditions in reference to the date (day of the year, DOY) of $50 \%$ shrimp larval emergence (E50\%) in spring (see below): (1) SST, (2) a mean SST warming rate for the first $30 \mathrm{~d}$ following E50\%, (3) the upper $(5$ to $30 \mathrm{~m})$ layer density stratification index, (4) an index of the thermally mixed layer depth (MLD) and (5) the depth of the $1^{\circ} \mathrm{C}$ isotherm.

For each given year, the rate of change in SST was not constant through time; thus, the mean warming rate $\left(W_{\text {rate }}\right)$, i.e. the rate of daily change in $\operatorname{SST}\left({ }^{\circ} \mathrm{C} \mathrm{d}^{-1}\right)$, was estimated as the cumulative sum of the mean slopes between every 2 adjacent days in the series, divided by the number of days considered:

$$
W_{\text {rate }}=\sum_{N}^{i}\left[\frac{1}{2}\left(\frac{y_{i+1}-y_{i}}{x_{i+1}-x_{i}}+\frac{y_{i}-y_{i-1}}{x_{i}-x_{i-1}}\right)\right] / N
$$

where $i$ represents the mean date of larval emergence and $N=30 \mathrm{~d}$ from $i$.

The available CTD profiles were processed to obtain mean values at $1 \mathrm{~m}$ depth intervals, and the data were used to estimate an upper-layer density stratification index as the difference in sigma- $t$ between 5 and $30 \mathrm{~m}$ divided by the depth interval. While sea-surface salinity (SSS) is the major determinant of density stratification in the upper water column, SST is a function of density stratification (Fig. 2B,C). Hence, to compensate for the lack of CTD profiles in early spring for some years, the relationship was used to generate the stratification index time series for each year from the daily SST time series.

Finally, an index of the $\operatorname{MLD}\left(Z_{\mathrm{m}}\right)$, defined as the depth at which water temperature difference from the surface was $\leq 1^{\circ} \mathrm{C}: Z_{\mathrm{m}}=\left(T_{0}-T_{\mathrm{z}}\right) \leq 1^{\circ} \mathrm{C}$ (Doyon \& Ingram 2000), and the depth of the $1^{\circ} \mathrm{C}$ isotherm were determined. Determination of the MLD is complex and often subjective; however, for the ice-free period in the GSL, it was concluded that temperature was a robust indicator of the upper well-mixed layer depth (Doyon \& Ingram 2000).

Sea-surface chlorophyll a data (SeaWiFS). SeaWiFS-derived chlorophyll a images were used to calculate daily mean values in a $3 \times 3$ pixel box $(3 \times 3 \mathrm{~km})$ centred on the location of the fixed monitoring station. By using information over the limited area of the monitoring station near the centre of the NW GSL, we minimise the problem of surface waters contaminated by coloured dissolved organic matter associated with freshwater runoff. The SeaWiFS images were processed using standard algorithms (SEADAS 4.8). These daily values were then further averaged into weekly means to derive a proxy for the timing of the spring bloom in the NW GSL.

Sea-ice data. The GSL has a subarctic climate, with sea ice present over most of the area from January to
April. Local sea ice dynamics are suspected to play an important role in the timing of the spring bloom (Le Fouest et al. 2005). The duration of the winter ice coverage in the NW GSL was estimated from digitised data $\left(0.5^{\circ}\right.$ latitude by $1^{\circ}$ longitude grid) from charts produced by the Canadian Ice Service of Environment Canada (Drinkwater et al. 1999, R. G. Pettipas pers. comm., Fisheries and Oceans Canada, Bedford Institute of Oceanography, Dartmouth, Nova Scotia). The DOY of last ice presence in the NW GSL was estimated as the time when no ice was recorded in any grid cell of the area selected for the analysis, that is, the DOY when the study area was completely free of ice.

Shrimp recruitment index and mean date of larval emergence. Northern shrimp samples were obtained from the commercial fishery in the NW GSL (Shrimp Fishing Area 10) between 1993 and 2005. Between 30 and 70 samples, representing between 7000 and 17000 individuals, were collected annually from April to October. The samples were brought back to the laboratory, where the individuals were measured to the nearest $0.1 \mathrm{~mm}$ (oblique carapace length, OCL) and sexed. Sex change occurs at about $21 \mathrm{~mm}$ OCL in the GSL, when shrimp are 4 to 5 yr old. The maturity stage of the females was determined by the presence (primiparous) or absence (multiparous) of sternal spines. The presence of eggs under the abdomen (ovigerous) was also noted.

Annual catch-at-length (in number) was obtained by summing monthly data previously weighted by the

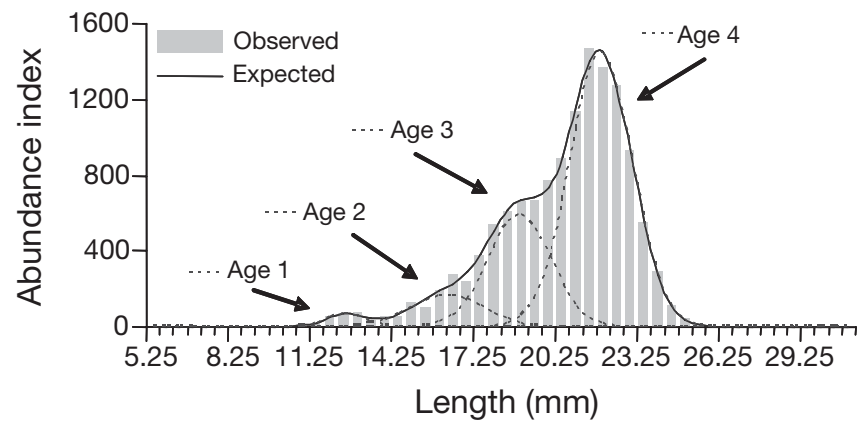

\begin{tabular}{|l|c|c|c|c|}
\hline & Mode 1 & Mode 2 & Mode 3 & Mode 4 \\
\hline Proportion & 0.01744 & 0.08344 & 0.25991 & 0.63920 \\
\hline Standard error & 0.00218 & 0.04789 & 0.06410 & 0.02265 \\
\hline Mean length & 12.3300 & 16.0437 & 18.6626 & 21.6582 \\
\hline Standard error & 0.0939 & 0.7476 & 0.1385 & 0.0506 \\
\hline Standard deviation & 0.6661 & 1.2990 & 1.1250 & 1.1388 \\
\hline Standard error & 0.0620 & 0.3770 & 0.1759 & 0.0250 \\
\hline \multicolumn{4}{|l|}{ Chi-squared $=33.7617(p=0.2905, \mathrm{df}=30)$} \\
\hline
\end{tabular}

Fig. 3. Pandalus borealis. Results from the modal analysis performed on the 1997 length-frequency distribution (LFD) of shrimp sample catches from the Gulf of St. Lawrence. Four normal components were identified, corresponding to Ages 1 to 4 (broken lines). Histogram: total observed LFD; solid line: expected LFD obtained from the model. The table presents the parameters and their standard errors estimated by the modal analysis 
catch of the month. The catch-at-length was then divided by the annual standardised fishing effort to obtain a length-frequency distribution that was considered as an index of abundance (number caught per hour fishing) of shrimp by size-classes (Savard \& Bouchard 2004). Modal analyses were performed on the male component of the annual length-frequency distributions using MIX 3.1 software (MacDonald \& Pitcher 1979).

For each year, 4 (and in some instances, 5) modes were identified, corresponding to Ages 1 to 4 (5) (see Fig. 3 for the analysis of the 1997 data). The proportion of each mode and, therefore, the estimate of abundance for each age group were obtained from the modal analysis. The run of the model that gave the lowest Chi-squared value calculated between the observed and expected frequencies was used to produce the index of abundance of the age groups. The standard error of the abundance indices corresponds to the standard error of the proportions estimated by the model (see Fig. 3).

However, because not all individuals of a cohort change sex during the same year, the estimated abundance of males of the fourth and fifth modes of a distribution does not necessarily correspond to the abundance of a single cohort. On the other hand, individuals of Age Group 1 were present in small numbers, but their abundance was not considered a valuable in-
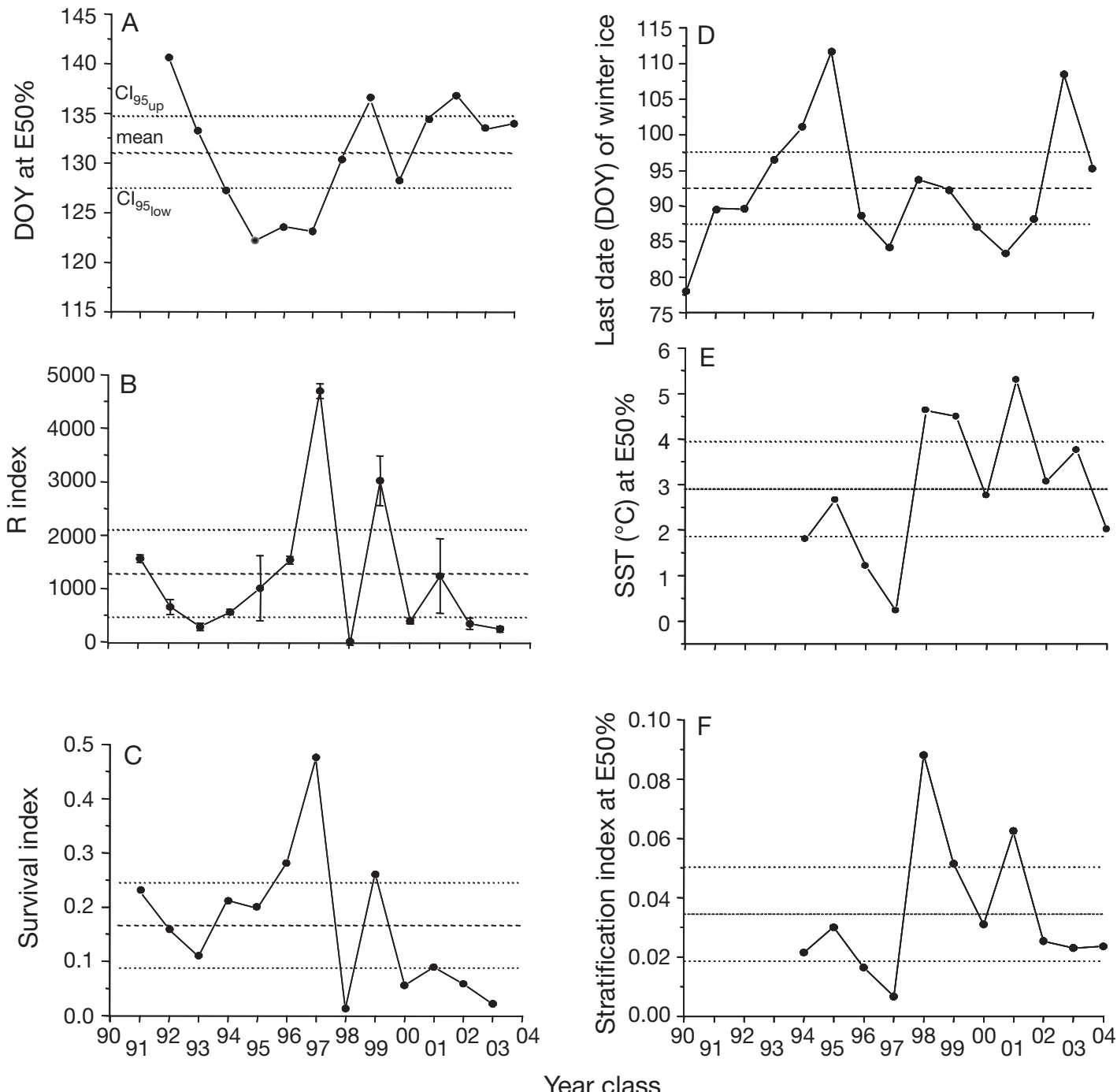

Fig. 4. Pandalus borealis. (A) Mean day of the year (DOY) at $50 \%$ shrimp larval emergence (E50\%) in the NW GSL (north-western Gulf of St. Lawrence) between 1992 and 2004. (B) Annual index of shrimp recruitment (R), 1991 to 2003 year-classes; error bars represent SE estimated by the modal analysis (see Fig. 3). (C) Annual index of larval survival, 1991 to 2003 year-classes. (D) DOY of the last presence of winter ice in the NW GSL between 1990 and 2004. (E) Mean daily SST in the NW GSL at the time of E50\%. (F) Density stratification index at the time of E50\%. For each graph, the horizontal lines illustrate the mean and the upper and lower $95 \%$ confidence intervals for the series 
dex of cohort strength because their capture by the fishing gears is variable depending on the fishing pattern and the growth rate of the cohort. Therefore, the estimated abundances of Age Groups 2 and 3 were considered as the most reliable indices of cohort abundance. Indeed, the correlation coefficient calculated between the abundance indices obtained from the modal analyses for the 1991 to 2002 cohorts estimated at Age 2 and at Age 3 in the following year was 0.96 . This indicates that the relative strength of a cohort persists over $2 \mathrm{yr}$ prior to sex change and that the fishing gears retain the individuals in proportion to their abundance in the population. The index of abundance of male shrimp estimated at Age 2 was selected as the recruitment index for the NW GSL (1991 to 2003 year-classes) because it allowed the inclusion of recent data in the series.

The samples collected at regular intervals from the beginning of the fishing season (ca. April 1, when most females carry eggs) were also used to determine the larval emergence dates. The ratio of ovigerous females to the total number of multiparous females (females that still carry eggs or have just released larvae) was calculated for each sample and plotted against the date when the catch was made. A logistic curve was adjusted for each year, and the date at which $50 \%$ of the females were still ovigerous was used as an estimate of the DOY at E50\%.

An index of the spawning stock biomass (SSB) was obtained by calculating the catch rate of multiparous females in the fishery in the months of April and May. Multiparous females that are caught in spring are responsible for the production of larvae during the same year, and their catch rate is considered a reliable index of their abundance. Therefore, a larval survival index was estimated by dividing the recruitment index (abundance of Age 2 shrimp) by the SSB index.

\section{RESULTS}

The DOY of larval emergence (E50\%) varied among years, but there seems to be a tendency for later dates starting in 1999 (Fig. 4A). The time series of shrimp recruitment index is characterised by large oscillations between high and low recruitment values among years (Fig. 4B). A test for autocorrelation, i.e. correlating the shrimp recruitment index in Year $i$ with the index in Year $i+1$ for up to $5 \mathrm{yr}$ (Lag-1 to Lag-5) revealed no significant correlations ( $\mathrm{p}>>0.05)$. There were 2 very strong shrimp year-classes after 1991 (1997 and 1999), but, with the exception of 2001, recruitment has been low in recent years (Fig. 4B). The larval survival index shows similarities with the recruitment index series, and again no significant autocorrelation was detected ( $p$ >> 0.05). There were high survival values in 1997 and 1999, but, interestingly, more contrast between the earlier years (before 1996) and the recent low survival index values (since 1998, with the exception of 1999; Fig. 4C).

Since 1990, the NW GSL has been free of winter ice from ca. April 1 (mean DOY = 92.5). However, between 1996 and 2002, winter ice tended to disappear earlier than the average (Fig. 4D). Since 1994, there seem to be 2 distinct periods in the SST at E50\% series; either SST was below average (1994 to 1997) or generally above average (1998 to 2003) (Fig. 4E). The upperlayer density stratification at E50\% was below average between 1994 and 1997, above average from 1998 to 2001 , with the exception of 2000, and remained below average from 2002 onwards (Fig. 4F).

In general, in the NW GSL, the daily mean SST remained cold $\left(\leq 0^{\circ} \mathrm{C}\right)$ until mid-April, but increased rapidly during the first half of May, at the time of shrimp larval emergence (Fig. 5). Note that the error bars ( $\pm 1 \mathrm{SD})$ in the daily mean SST series also illustrate strong interannual variability during the period of vernal warming in the NW GSL.

Despite the short time series, there appears to be a consistent negative relationship between the shrimp recruitment index and daily mean SST at E50\% (Fig. 6A). On the other hand, there is evidence of a marginally significant $(p=0.075)$ positive relationship between the recruitment index and SST warming rate in early spring (Fig. 6B). The depth of the $1^{\circ} \mathrm{C}$ isotherm and the thermally mixed layer depth also appear positively related to the recruitment index (Fig. 6C,D). The shrimp larval survival index was significantly negatively correlated with daily mean SST at E50\%

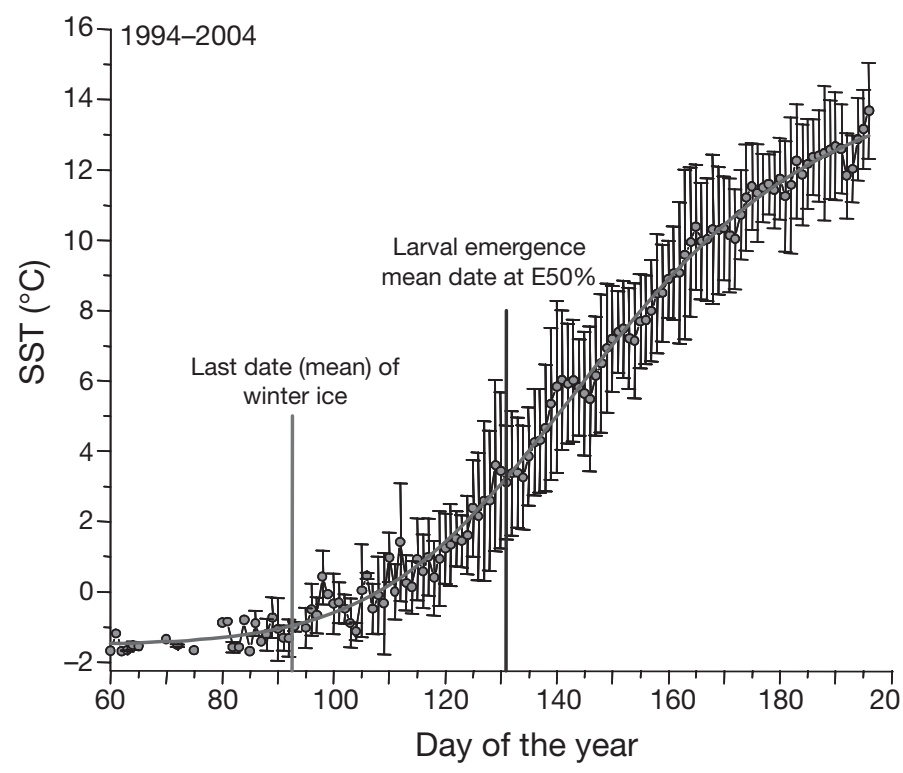

Fig. 5. Evolution of the daily mean $( \pm 1 \mathrm{SD}) \mathrm{SST}$ in spring between 1994 and 2004 in the north-western Gulf of St. Lawrence 

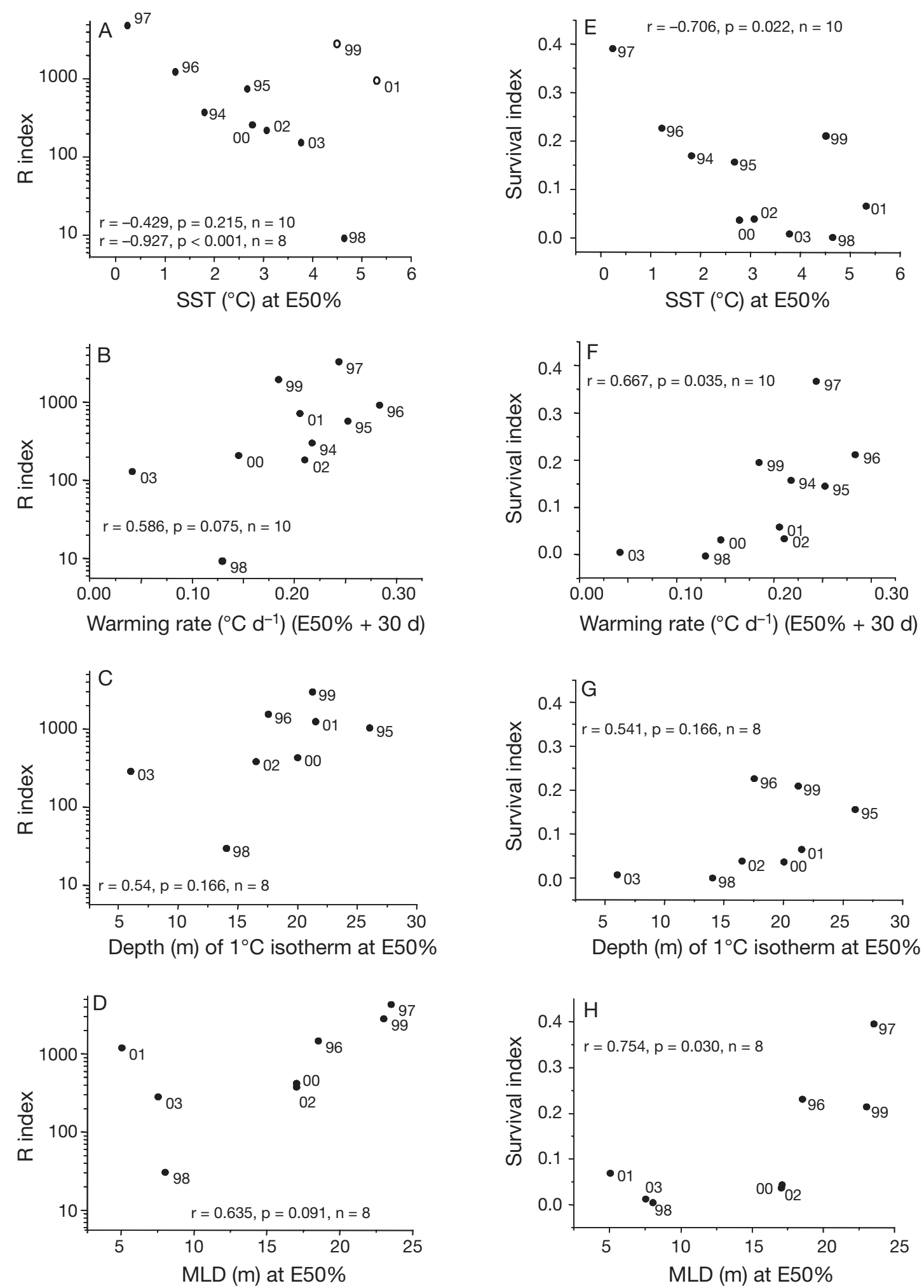

Fig. 6. Pandalus borealis. Correlation between: (A) mean SST at $50 \%$ larval emergence (E50\%) and shrimp recruitment (R) index ( $\log$ abundance of Age 2 shrimp); Pearson's coefficients are presented for all data $(\mathrm{n}=10)$ and for correlations that exclude 2 'outlier' years (1999 and 2001); (B) SST warming rate for $30 \mathrm{~d}$ following the E50\% date and R index; (C) depth of the $1{ }^{\circ} \mathrm{C}$ isotherm at E50\% and R index; (D) (thermally) mixed layer depth (MLD) at E50\% and R index; (E) SST at E50\% and larval survival index; (F) SST warming rate for $30 \mathrm{~d}$ following the E50\% date and larval survival index; (G) depth of the $1{ }^{\circ} \mathrm{C}$ isotherm at E50 \% and larval survival index; (H) MLD at E50\% and larval survival index 
(Fig. 6E). The shrimp larval survival index was significantly positively correlated with the SST warming rate (Fig. 6F). The positive relationship between the larval survival index and the depth of the $1^{\circ} \mathrm{C}$ isotherm was not statistically significant (Fig. 6G), but a significant positive correlation was found between the larval survival index and the mixed layer depth (Fig. 6H).

On the other hand, the last date of winter ice presence in the NW GSL was not correlated to the indices of shrimp recruitment $(\mathrm{r}=-0.260, \mathrm{p}=0.38$; $\mathrm{r}=0.225$, $\mathrm{p}=0.458$ for the recruitment index and survival index, respectively). Moreover, the last date of winter ice presence was not correlated to SST at E50\% ( $r=0.043$, $\mathrm{p}=0.898$ ), nor to the density stratification index at E50\% ( $r=-0.107, p=0.752)$.

Satellite-derived sea-surface chlorophyll a concentrations (SSC) for the NW GSL have been available from SeaWiFS satellite data since 1998 only. Weekly mean values, as proxies of the timing of the spring bloom, are shown for each year, and it appears that the date of $50 \%$ shrimp larval emergence (corresponding to Week 19 or 20) is generally coincident with the yearly period of maximum SSC (Fig. 7A). Furthermore, although the short time series limits the possibility of detecting statistically significant links, since 1998, the relationships between the indices of shrimp recruitment success and the estimated SSC show a positive trend, suggesting that the magnitude of the spring bloom might influence shrimp larval survival (Fig. 7B).

The number of significant correlations in the analysis is influenced to some degree by cross-correlations among some variables, e.g. MLD and SST (not shown). Nonetheless, the different relationships observed are indications that spring oceanographic conditions in the upper layer of the water column can explain shrimp larval survival and recruitment success in the NW GSL. In an attempt to present a synoptic view of what conditions are more or less favourable to larval survival, each data point for each variable was categorised as 'below average', 'average', or 'above average', according to its position relative to the series mean and the upper and lower $95 \%$ confidence intervals of the mean (see Fig. 4 and Table 2). The earlier years of the series (1994 to 1997) show average or high shrimp larval survival indices that seem related to years of early emergence and a weakly stratified upper water column; hence, low SST during larval emergence in the spring, followed by high warming rates of the surface water (Table 2). Conversely, since 1998, later emergence dates, stronger stratification and warmer SST during larval emergence seem to have resulted in the lower larval survival indices found in recent years (with the exception of 1999; Table 2).

\section{DISCUSSION}

The general pattern revealed by our analysis is that northern shrimp Pandalus borealis larval emergence in spring during a period of weak density stratification (low SST) and deep (thermally) mixed layer, followed by relatively high warming rates of the upper layer of the water column, favours larval survival and recruitment success in the NW GSL. In early spring, the upper water column is rich in nitrate following deep convection during the previous fall/winter (Plourde \& Therriault 2004). However, an early and strong stratification and a shallow MLD will likely result in a rapid depletion of nutrients and reduce the potential for high and sustained phytoplankton production. We suggest that the combined observed relationships support the idea that oceanographic conditions affecting the initiation of the spring diatom bloom and sustaining high levels of primary and secondary production at the time of larval emergence and development - the match/ mismatch hypothesis as proposed by Cushing (1990) are favourable to northern shrimp recruitment success. Indeed, support for this conclusion can be found by a closer examination and comparison of the conditions associated with the extreme $(1997,1998,1999)$ and average (2001) recruitment years.

In 1997, the year of maximum recruitment for the time series, there were strong negative SST anomalies from early May to mid-June (Fig. 8), suggesting that the weak stratification and deep MLD present at E50\% (see Fig. 6) persisted for the period of development of the first 2 or 3 larval stages. In contrast, shrimp recruitment in 1998 was extremely low in conjunction with strong positive daily SST anomalies (i.e. strong upper layer stratification, shallow MLD; Fig. 6) following the date of $50 \%$ larval emergence (Fig. 8). In 1999, the combination of late larval emergence, relatively strong stratification and warm surface water should have resulted in average or low larval survival. However, 1999 was exceptional with very strong positive late winter/early spring temperature anomalies and early production (Drinkwater et al. 2000, Head et al. 2005), but the daily SST anomalies were about normal at the time of E50\% (see Fig. 8), indicating an important weakening of the stratification and deep vertical mixing in the upper layer in May and June, conditions that apparently were beneficial for larval survival. In 2001, conditions seemed similar to those in 1999 (see Table 2), but in 2001 the water column remained strongly stratified (shallow MLD; Fig. 6) following larval emergence as inferred by the strong positive SST anomaly (Fig. 8), and larval survival was only average. Moreover, according to our analysis, the DOY at $50 \%$ larval emergence generally coincides well with the period of high SSC concentrations, and chlorophyll a 

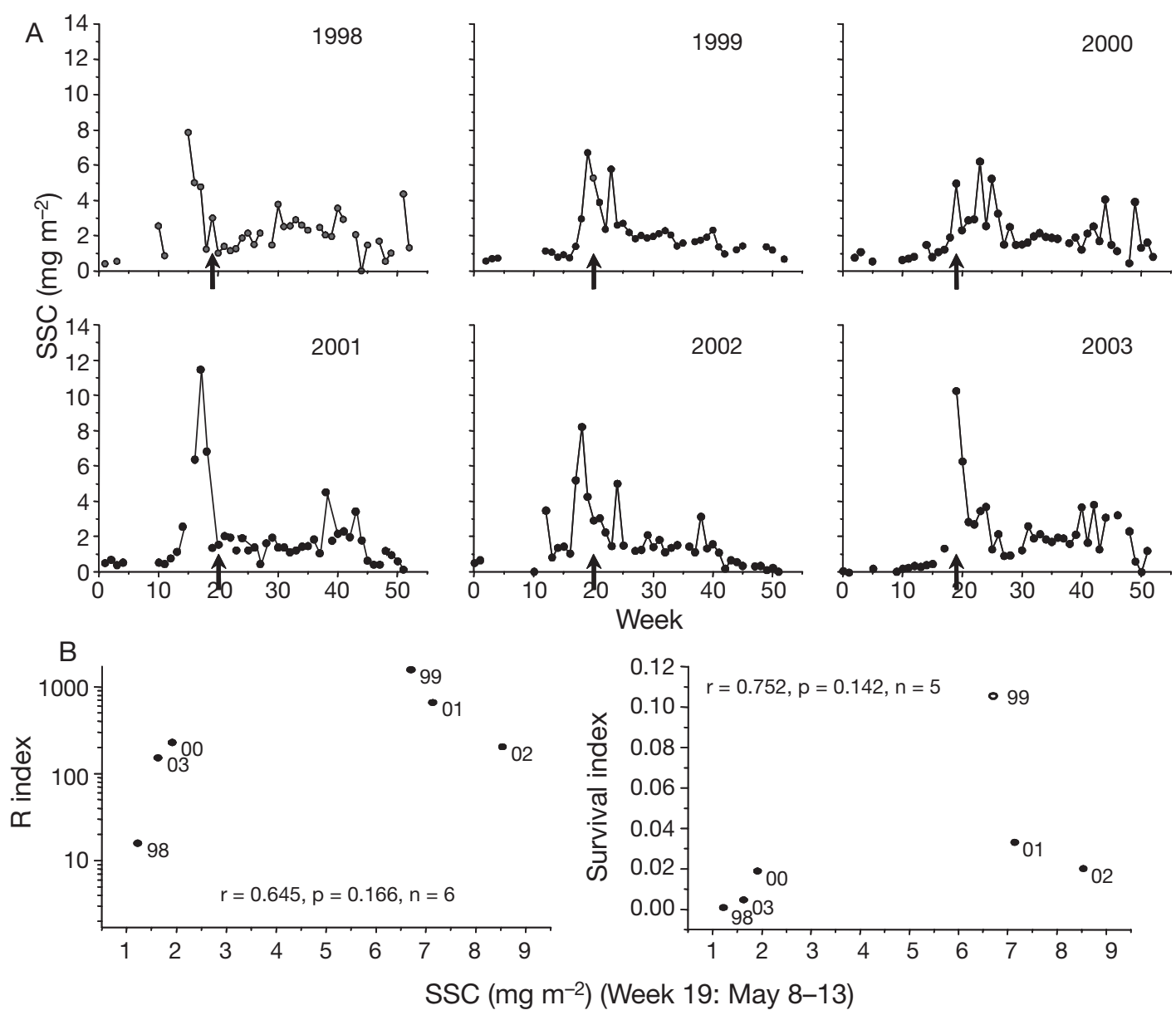

Fig. 7. Pandalus borealis. (A) Weekly mean time series of sea-surface chlorophyll a (SSC) concentrations (from SeaWiFS) near the fixed monitoring station for each year between 1998 and 2003. The short vertical arrows on the $x$-axes indicate the dates (i.e. week) of shrimp 50\% larval emergence for each year. (B) Pearson's correlations between the shrimp recruitment (R) index and larval survival index and SSC concentration for Week 19

Table 2. Pandalus borealis. Synopsis of conditions for good and poor larval survival of northern shrimp in the north-western Gulf of St. Lawrence. The qualifier attached to each value in parentheses refers to the position of the data point relative to the mean and $95 \%$ confidence intervals of the series (see Fig. 3). All values within the upper and lower $95 \%$ limits are 'average' or 'moderate'; values below the lower $95 \%$ interval are 'early', 'low', etc. and values above the upper $95 \%$ limit are 'late', 'high', etc. Year: year-class; DOY at E50\%: day of the year at $50 \%$ larval emergence; Stratification: density stratification in the upper layer; SST: sea-surface temperature; Warming rate: SST warming rate

\begin{tabular}{|c|c|c|c|c|}
\hline Year & DOY at E50\% & $\begin{array}{c}\text { Stratification ( } \Delta \text { sigma- } t, 5-30 \mathrm{~m}) \text { and } \\
\operatorname{SST}\left({ }^{\circ} \mathrm{C}\right) \text { at E } 50 \%\end{array}$ & $\begin{array}{l}\text { Warming rate }\left({ }^{\circ} \mathrm{C} \mathrm{d}^{-1}\right) \\
\text { for } 30 \mathrm{~d} \text { from } \mathrm{E} 50 \%\end{array}$ & Survival index \\
\hline 1994 & Early (127) & Average $(0.0216) \rightarrow$ Avg/cold (1.80) & Moderate $(0.217)$ & Average \\
\hline 1995 & Early (122) & Average $(0.0300) \rightarrow$ Average $(2.67)$ & High (0.252) & Average \\
\hline 1996 & Early (123) & Weak (0.0165) $\rightarrow$ Cold $(1.21)$ & High (0.283) & High \\
\hline 1997 & Early (123) & Weak (0.0067) $\rightarrow$ Cold (0.23) & High (0.243) & High \\
\hline 1998 & Average (130) & High $(0.0880) \rightarrow$ Warm $(4.64)$ & Low $(0.129)$ & Low \\
\hline 1999 & Late (136) & Avg/High $(0.0515) \rightarrow$ Warm $(4.49)$ & Moderate $(0.184)$ & High \\
\hline 2000 & Average (128) & Average $(0.0310) \rightarrow$ Average $(2.76)$ & Moderate/Low (0.145) & Low \\
\hline 2001 & Avg/Late (134) & High $(0.0625) \rightarrow$ Warm (5.30) & Moderate $(0.205)$ & Avg/low \\
\hline 2002 & Late (137) & Average $(0.0254) \rightarrow$ Average $(3.06)$ & Moderate $(0.210)$ & Low \\
\hline 2003 & Average (133) & Average $(0.0230) \rightarrow$ Average $(3.76)$ & Low $(0.041)$ & Low \\
\hline 2004 & Average (134) & Average $(0.0236) \rightarrow$ Average $(2.02)$ & Moderate $(0.184)$ & \\
\hline
\end{tabular}



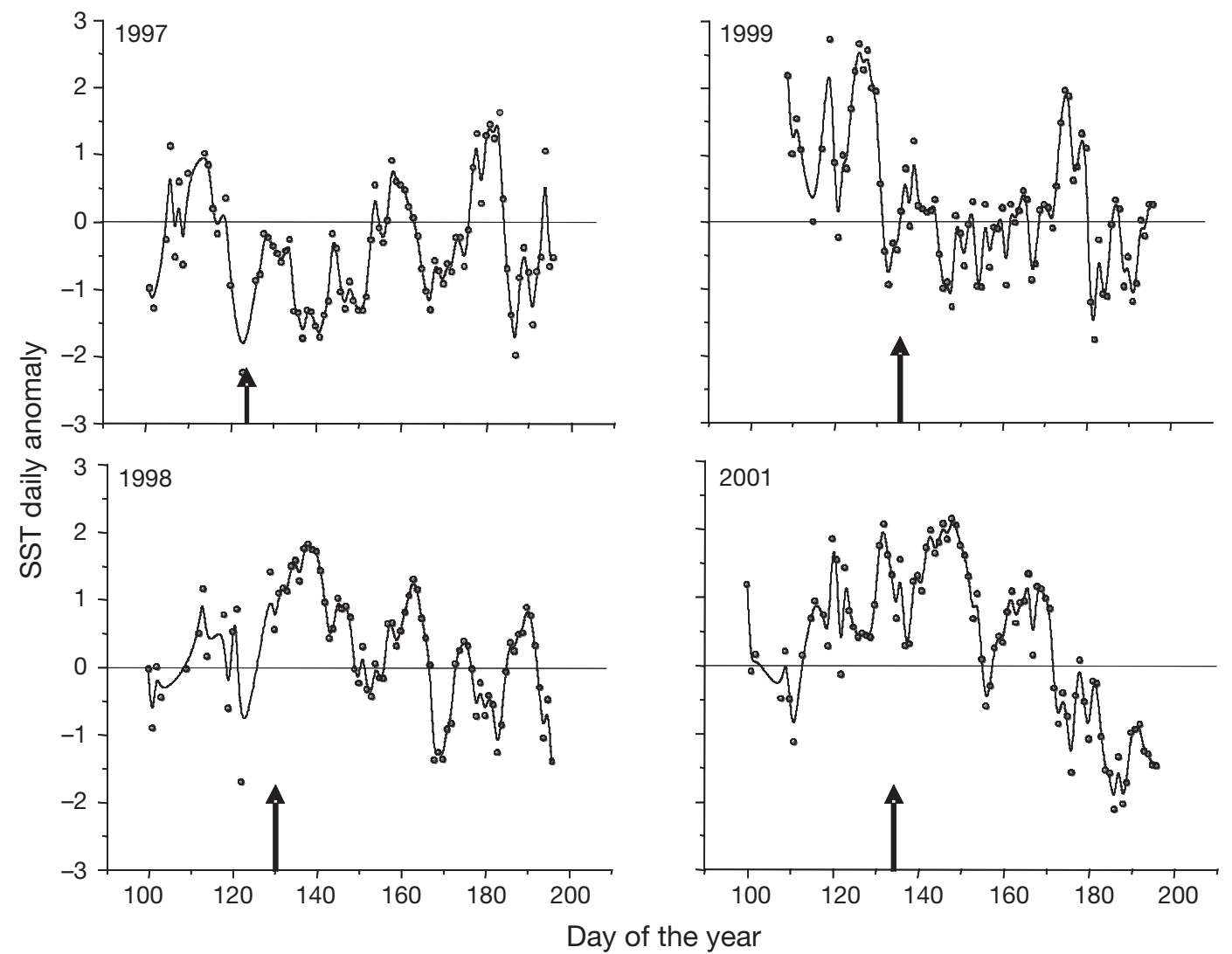

Fig. 8. Pandalus borealis. Time series of the standardised daily mean SST anomaly $\left(\left[T_{i j}-T_{i}\right] / \mathrm{SD}_{T i}\right.$, where $T_{i j}$ is the daily mean SST for Day $i$ in Year $j, T_{i}$ is the daily mean SST for Day $i$ [for all years] and $\mathrm{SD}_{T i}$ is the standard deviation of $T_{i}$ ) for the extreme (1997 and 1998) and 'outlier' years (1999 and 2001) of the series (see Fig. 6). The vertical arrows indicate the date at E50\%

concentration (magnitude of the spring bloom) might also influence larval survival.

However, under laboratory conditions, shrimp larvae show better development and growth performance when reared at water temperatures $>3^{\circ} \mathrm{C}$ (Ouellet \& Chabot 2005), and a slow rate of increase of water temperature was shown to enhance larval growth and survival (Rasmussen \& Tande 1995). The first larval stages also actively remain within the upper, warmer $\left(>1^{\circ} \mathrm{C}\right)$ layer of thermally stratified water columns (Ouellet \& Allard 2006). Hence, the observed positive relationships between the thermally mixed upper layer depth, the depth of the $1^{\circ} \mathrm{C}$ isotherm and the larval survival index suggest the alternative hypothesis that a relatively deep and warm upper layer is favourable to northern shrimp larval development and survival and recruitment success in the NW GSL.

The timing of food production and warming of the surface water mass in spring could also act synergistically. Larval development is sensitive to water temperature, but food quality may be crucial to maximise growth, especially for the late developmental stages (e.g. Ouellet \& Chabot 2005). On the other hand, low water temperature could impair feeding efficiency of larvae even if food items are abundant (e.g. Arctic cod; Michaud et al. 1996).

The match/mismatch hypothesis of recruitment success in marine populations has been notoriously difficult to prove or disprove, and early larval feeding success is likely not the only factor affecting recruitment (e.g. Leggett \& Deblois 1994). Our analysis is also inferential, but many aspects of northern shrimp ecology in the NW GSL add support to the hypothesis. Simple mathematical simulations of the match/mismatch scenario indicate that recruitment variability is dependent on the duration of spawning (larval emergence) in relation to the spring bloom (Mertz \& Myers 1994). Contrary to many marine fish populations with sequential spawning and/or a protracted spawning season, northern shrimp larval emergence is of short duration (mean duration between 25 and $75 \%$ larval emergence $\approx 12 \mathrm{~d}$ ). It is therefore possible that, because of this short duration, an emergence can happen when the oceanographic conditions are not optimal for larval survival. In addition, as revealed by our analysis, the timing of larval emergence can also vary through the years, possibly due to interannual fluctuations in the deep-water temperature in the GSL. 
Indeed, temperature fluctuations in deep water, where ovigerous females spend most of the egg incubation period, affect egg development and survival, as well as larval emergence time (Brillon et al. 2005).

Much less well understood are the controlling factors for the initiation and the temporal evolution of the spring biological production in this region of the GSL. The assumption that the physical structure and dynamics of the upper water column determine the characteristics of biological production is critical to our interpretation. Although we cannot present empirical evidence that interannual variability in the timing and amplitude of the phytoplankton production or in species/stage-specific abundance and community structure of the mesozooplankton is associated with the physical characteristics of the upper water column, the inferred relationships are based on well-established oceanographic processes. In early spring, increased photoperiod and stratification and high nutrient concentrations in the upper layer from the previous fall/winter deep convection are likely to influence the timing and amplitude of the spring bloom (Le Fouest et al. 2005). When strong stratification and a shallow MLD are established early, the upward flux of nutrients is inhibited and the bloom will likely be of short duration, whereas weaker stratification and moderate mixing (deeper MLD) replenishing the surface nutrient field will support enhanced phytoplankton and microand mesozooplankton growth (e.g. Kiørboe 1993, Doyon et al. 2000).

First feeding may not be the only critical moment for larval survival: the temporal availability of adequate prey may be critical during older larval stages. The duration of Pandalus borealis larval development is long ( $\sim 70 \mathrm{~d})$ and proceeds through several developmental stages (Ouellet \& Chabot 2005). Only the first larval stage may need phytoplankton cells for successful feeding; the later stages depend on mesozooplankton production (Rasmussen et al. 2000, Harvey \& Morrier 2003). Indeed, Ouellet et al. (1995) suggested that concentrations of copepod developmental stages affect shrimp nutritional (lipids) condition in the northern GSL. In the northern GSL, as in most northern latitude regions, the spring bloom is of short duration. Subsequent mixing events may then become important for the successful development of the mesozooplankton community needed for older larval stages. High abundances of the important copepod Calanus finmarchicus over-winter (diapause) in the deep waters of the NW GSL, and they should rise to near the surface to produce eggs in spring (taking advantage of the diatom bloom). Although seasonal and interannual variability in the abundance of the early developmental stages of copepod species are observed in the NW GSL, little is known about the factors (local production vs. advective processes) controlling production and abundance (S. Plourde pers. comm., Fisheries and
Oceans Canada, Maurice Lamontagne Institute, MontJoli, Quebec). A simulation study suggested that surface water circulation plays a significant role in the net transport of the early developmental stages from the NW GSL toward the central gulf, while some importation to the NW GSL may come from the estuary or, especially, from the deeper central GSL region (Zakardjian et al. 2003). However, a much more detailed model of copepod production and cohort development following the bloom is still needed for all regions of the GSL.

An assessment of the transport of shrimp larvae in the NW GSL (Ouellet \& Lefaivre 1994) concluded that water mass circulation was favourable to the maintenance of the larval cohorts within the boundary of the system, and that ecological factors affecting larval survival in the water column are probably responsible for the horizontal pattern of abundance distribution of the later larval stages. Despite recent modelling efforts, our knowledge of the small-scale dynamics and retention time of the water masses of that region of the GSL is still limited (no recent empirical estimates, no Eulerian drifter studies, etc.). Therefore, our analysis and this discussion are limited to local ecological processes that influence larval survival. Moreover, local emergence and the concurrent presence of successive larval stages at various sites in the NW GSL support the proposition that local larval development, growth and survival contribute to recruitment to the local shrimp population (Ouellet \& Lefaivre 1994, Ouellet et al. 1995, Ouellet \& Allard 2006).

Finally, we suggest that our capability to anticipate northern shrimp recruitment fluctuations in the GSL, and the impacts of climate change on shrimp populations in the Northwest Atlantic in general, can be significantly improved by integrating an atmosphereocean model of the seasonal characteristics of the upper water column and its control of the initiation of the spring bloom, a shrimp population model of total egg production and development (emergence) time, and a bio-physical model of the development of the plankton community coupled to a model (IBM type) of shrimp early life-stage dynamics.

Acknowledgements. We are grateful to $\mathrm{H}$. Bouchard and to numerous technicians who collected and processed the shrimp samples. We also acknowledge the support of Heidi Maass from the Bedford Institute of Oceanography who provided the SeaWiFS-derived chlorophyll time series. We thank S. Plourde and J. A. Gagné for comments and discussion on the manuscript, and L. Devine for revision of the English text. The comments and suggestions by 4 anonymous referees were also instrumental in the amelioration of a first version of the manuscript.

\section{LITERATURE CITED}

Anderson PJ (2000) Pandalid shrimp as indicators of ecosystem regime shift. J Northwest Atl Fish Sci 27:1-10

Brillon S, Lambert Y, Dodson JJ (2005) Egg survival, embryonic 
development, and larval charactersitics of northern shrimp (Pandalus borealis) females subject to different temperature and feeding conditions. Mar Biol 147:895-911

Cushing D (1990) Plankton production and year-class strength in fish populations: an update of the match/mismatch hypothesis. Adv Mar Biol 26:249-293

Doyon P, Ingram RG (2000) Seasonal upper-layer T-S structure in the Gulf of St. Lawrence during the ice-free months. Deep-Sea Res Part II 47:385-413

Doyon P, Klein B, Ingram RG, Legendre L, Tremblay JÉ, Therriault JC (2000) Influence of wind mixing and upper-layer stratification on phytoplankton biomass in the Gulf of St. Lawrence. Deep-Sea Res Part II 47:415-433

Drinkwater KF, Pettipas RG, Bugden GL, Langille P (1999) Climatic data for the northwest Atlantic: a sea ice database for the Gulf of St. Lawrence and the Scotian Shelf. Can Tech Rep Hydrogr Ocean Sci 199

Drinkwater KF, Pettipas RG, Petrie WM (2000) Overview of meteorological and sea ice conditions off eastern Canada during 1999. Res Doc 2000/59, Canadian Stock Assessment Secretariat, Ottawa

Edwards M, Richardson AJ (2004) Impact of climate change on marine pelagic phenology and trophic mismatch. Nature 430:881-884

El-Sabh MI (1976) Surface circulation pattern in the Gulf of St. Lawrence. J Fish Res Board Can 33:124-138

Fuentes-Yaco C, Koeller PA, Sathyendranath S, Platt T (2007) Shrimp (Pandalus borealis) growth and timing of the spring phytoplankton bloom on the NewfoundlandLabrador Shelf. Fish Oceanogr 16:116-129

Han G (2004) Sea level and surface current variability in the Gulf of St. Lawrence from satellite altimetry. Int J Remote Sensing 25:5069-5088

Harvey M, Morrier G (2003) Laboratory feeding experiments on zoea of northern shrimp Pandalus borealis fed with natural zooplankton. Mar Ecol Prog Ser 265:165-174

Head EJH, Brickman D, Harris LR (2005) An exceptional haddock year class and unusual environmental conditions on the Scotian Shelf in 1999. J Plankton Res 27:597-602

Kiørboe T (1993) Turbulence, phytoplankton cell size, and the structure of pelagic food webs. Adv Mar Biol 29:1-72

Koutitonsky VG, Bugden GL (1991) The physical oceanography of the Gulf of St. Lawrence: a review with emphasis on the synoptic variability of the motion. In: Therrialut JC (ed) The Gulf of St. Lawrence: Small ocean or big estuary? Can Spec Publ Fish Aquat Sci 113:57-90

Le Fouest V, Zakardjian B, Saucier FJ, Starr M (2005) Seasonal versus synoptic variability in planktonic production in a high-latitude marginal sea: the Gulf of St. Lawrence (Canada). J Geophys Res C 110:09012, doi: 10.1029/ 2004JCOO2423

Leggett WC, Deblois E (1994) Recruitment in marine fishes: Is it regulated by starvation and predation in the egg and larval stages? Neth J Sea Res 32:119-134

MacDonald PDM, Pitcher TJ (1979) Age-groups from size-frequency data: a versatile and efficient method of analysing distribution mixtures. J Fish Res Board Can 36:987-1001

Mertz G, Myers RA (1994) Match/mismatch predictions of spawning duration versus recruitment variability. Fish Oceanogr 3:236-245

Michaud J, Fortier L, Rowe P, Ramseier R (1996) Feeding success and survivorship of Arctic cod larvae, Boreogadus saida, in the Northeast Water Polynya (Greenland Sea). Fish Oceanogr 5:120-135

Ouellet M, Petrie B, Chassé J (2003) Temporal and spatial scales of sea-surface temperature variability in Canadian Atlantic waters. Can Tech Rep Hydrogr Ocean Sci 228

Editorial responsibility: Howard Browman (Associate Editorin-Chief), Storebø, Norway
Ouellet P, Allard JP (2006) Vertical distribution and behaviour of shrimp Pandalus borealis larval stages in thermally stratified water columns: laboratory experiments and field observations. Fish Oceanogr 15:373-389

Ouellet P, Chabot D (2005) Rearing Pandalus borealis (Krøyer) in the laboratory. I. Development and growth at three temperatures. Mar Biol 147:869-880

Ouellet P, Lefaivre D (1994) Vertical distribution of northern shrimp (Pandalus borealis) larvae in the Gulf of St. Lawrence; implications for trophic interactions and transport. Can J Fish Aquat Sci 51:123-132

Ouellet P, Taggart CT, Frank KT (1992) Lipid condition and survival in shrimp (Pandalus borealis) larvae. Can J Fish Aquat Sci 49:368-378

Ouellet P, Taggart CT, Frank KT (1995) Early growth, lipid composition, and survival expectations of shrimp Pandalus borealis larvae in the northern Gulf of St. Lawrence. Mar Ecol Prog Ser 126:163-175

Parsons DG, Colbourne EB (2000) Forecasting fishery performance for northern shrimp (Pandalus borealis) on the Labrador Shelf (NAFO Division 2HJ). J Northwest Atl Fish Sci 27:11-20

Pedersen SA, Storm L (2002) Northern shrimp (Pandalus borealis) recruitment in West Greenland waters, Part II. Lipid classes and fatty acids in Pandalus shrimp larvae: implications for survival expectations and trophic relationships. J Northwest Atl Fish Sci 30:47-60

Platt T, Fuentes-Yaco C, Frank KT (2003) Spring algal bloom and larval fish survival. Nature 423:398-399

Plourde J, Therriault JC (2004) Climate variability and vertical advection of nitrates in the Gulf of St. Lawrence, Canada. Mar Ecol Prog Ser 279:33-43

Rasmussen T, Tande K (1995) Temperature-dependent development, growth and mortality in larvae of the deep-water prawn Pandalus borealis reared in the laboratory. Mar Ecol Prog Ser 118:149-157

Rasmussen T, Aschan M, Christiansen JS (2000) The implementation of laboratory studies to shrimp recruitment modelling - a brief review of experimental procedures. ICES CM 2000/R:07

Saucier JF, Roy F, Gilbert D (2003) Modelling the formation and circulation processes of water masses and sea ice in the Gulf of St. Lawrence. J Geophys Res C 118:3269, doi: 10.1029/2000JC000686

Savard L, Bouchard H (2004) Estuary and Gulf of St. Lawrence shrimp (Pandalus borealis) stock status in 2003. Res Doc 2004/091, DFO Canada Science Advisory Secretariat, Ottawa

Savard L, Bouchard H, Couillard P (2003) Revue de la pêche à la crevette nordique (Pandalus borealis) dans l'estuaire et le golfe du Saint-Laurent pour la période 1965-2000. Rapp Tech Can Sci Halieut Aquat 2465

Savenkoff C, Savard L, Morin B, Chabot D (2006) Main prey and predators of northern shrimp (Pandalus borealis) in the northern Gulf of St. Lawrence during the mid-1980s, mid-1990s, and early 2000s. Can Tech Rep Fish Aquat Sci 2639

Stickney AP, Perkins HC (1981) Observations on the food of the larvae of the northern shrimp, Pandalus borealis Kroyer (Decapoda, Caridea). Crustaceana 40:36-49

Zakardjian BA, Sheng J, Runge JA, McLaren I, Plourde S, Thompson KR, Gratton Y (2003) Effects of temperature and circulation on the population dynamics of Calanus finmarchicus in the Gulf of St. Lawrence and Scotian Shelf: study with a coupled, three-dimensional hydrodynamic, stage-based life-history model. J Geophys Res C 108:8016, doi: 10.1029/2002JC001410 